This item was submitted to Loughborough's Research Repository by the author.

Items in Figshare are protected by copyright, with all rights reserved, unless otherwise indicated.

\title{
Measuring political brand equity: a consumer oriented approach
}

PLEASE CITE THE PUBLISHED VERSION

http://dx.doi.org/10.1108/03090561011020534

\section{PUBLISHER}

(c) Emerald Group Publishing Limited

\section{VERSION}

AM (Accepted Manuscript)

\section{LICENCE}

CC BY-NC-ND 4.0

\section{REPOSITORY RECORD}

French, Alan, and Gareth Smith. 2019. "Measuring Political Brand Equity: A Consumer Oriented Approach". figshare. https://hdl.handle.net/2134/14793. 
This item was submitted to Loughborough's Institutional Repository (https://dspace.lboro.ac.uk/) by the author and is made available under the following Creative Commons Licence conditions.

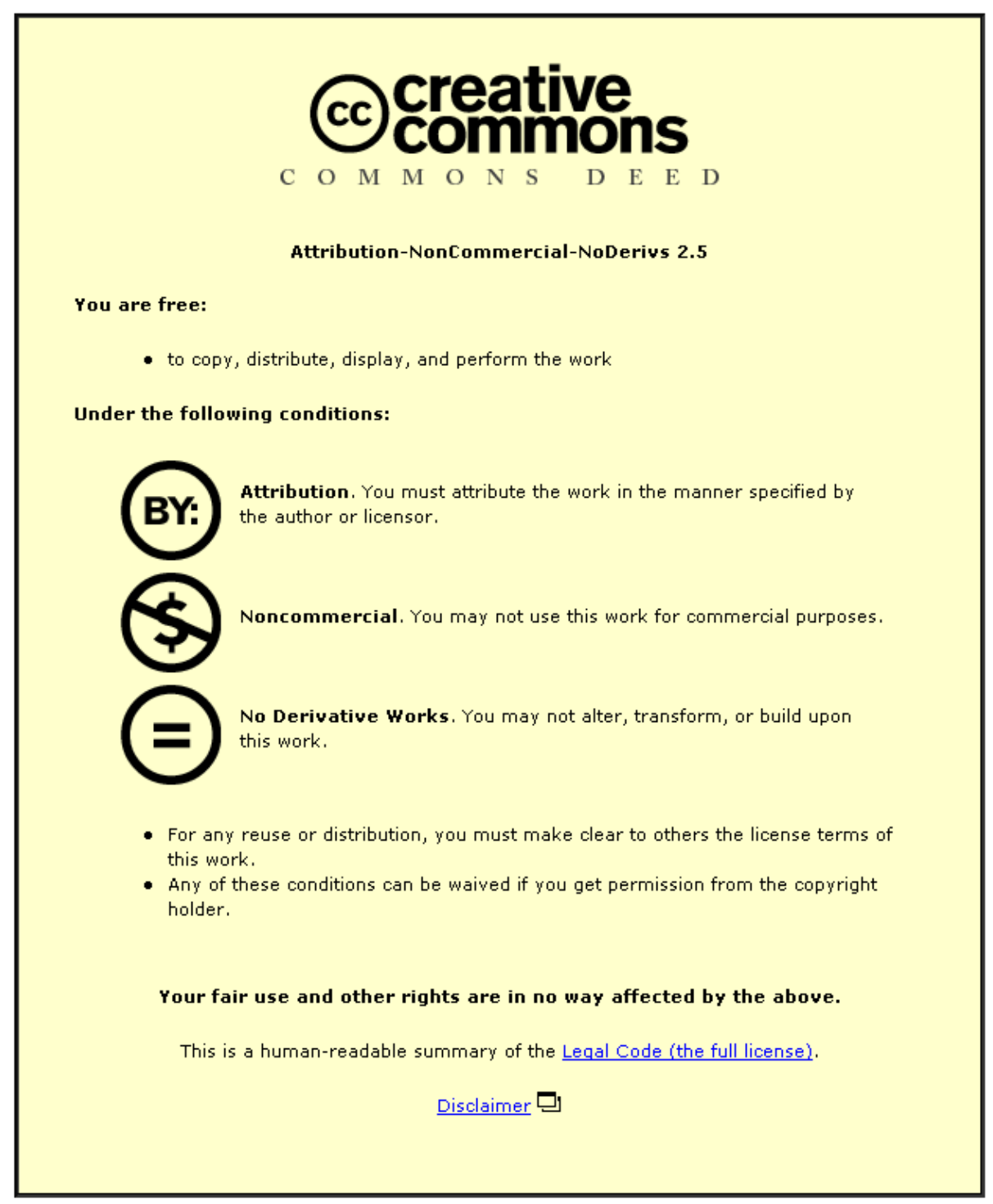

For the full text of this licence, please go to: http://creativecommons.org/licenses/by-nc-nd/2.5/ 


\title{
Measuring Political Brand Equity: A Consumer Oriented Approach.
}

\author{
Alan French and Gareth Smith* \\ Loughborough University, UK
}

*The Authors:

Dr Alan French, Lecturer in Management Science, Loughborough University Business School, Loughborough University, Loughborough, Leicestershire LE11 3TU, UK.

Tel: +44 (0)1509 223199; fax: +44 (0)1509 223960; email: A.P.French@lboro.ac.uk

Gareth Smith, Senior Lecturer in Marketing, Loughborough University Business School, Loughborough University, Loughborough, Leicestershire LE11 3TU, UK.

Tel: +44 (0)1509 223126; fax: +44 (0)1509 223960; email: I.G.Smith@lboro.ac.uk

\section{Research Paper}

Keywords: Political Marketing Brand Associations Equity Mapping 


\title{
Measuring Political Brand Equity: A Consumer Oriented Approach.
}

\section{Research Paper}

\begin{abstract}

\section{Purpose}

To develop understanding of how voters view the political brand by analysing the mental maps that voters create when asked to think about a political party. The analysis is both in terms of the nature of the maps and also in terms of the equity associated with a map.
\end{abstract}

\section{Methodology}

A consumer-oriented approach is developed for mapping the political brand. The brand maps are analysed to discern brand characteristics. Furthermore, methods are developed to assess the power of political brands and concomitantly, political brand equity.

\section{Findings}

The method provides interesting insights into the nature and equity of brand associations for the two main political protagonists, i.e. Conservative and Labour. Key branded characteristics are highlighted for each party, both in terms of general structure, and also those associations which form a central role in voters' maps. For the partisan sample chosen, both parties are shown to have strong brand equity, with the Conservatives slightly stronger than Labour.

\section{Practical implications}

The method is straightforward to apply and provides important information to political marketers about the nature and power of the associations held in memory by voters. Taking a wider stance, the approach can be applied to any branding situation.

\section{Originality/value}


This paper provides a means by which a brand mapping process, new to politics, can be combined with methods facilitating the analysis of brand maps to produce a means by which brand equity can be measured.

\section{Keywords: Political Marketing Brand Associations Equity Mapping}

\section{Introduction}

The concept of political parties as brands is now commonplace and part of a general dispersion of branding from its original, consumer marketing origins. Indeed, "branding principles have been applied in virtually every setting where consumer choice of some kind is involved, e.g., with physical goods, services, retail stores, people, organisations, places or ideas” (Keller, 2002, p. 151) (our italics). It is axiomatic that political parties are organisations where politicians seek to exchange ideas and promises for electoral support. However, Keller concludes that "As branding is applied in more and more different settings, brand theory and best practice guidelines need to be refined to reflect the unique realities of those settings” (2002, p. 171).

Politics has already been shown to be different to other, commercial markets (Lock and Harris, 1996; Butler and Collins, 1999; O’Shaugnessy, 2001; Henneberg, 2006). The purpose of this paper is therefore not to be prescriptive about the application of branding practices in politics but rather to develop understanding of how voters view the political brand. It does this by applying consumer learning theory to the political brand. From this theoretical/conceptual underpinning, and using an empirically validated methodology for measuring brands, the paper develops a new consumer-oriented approach for mapping the political brand. It also develops a method for assessing the power of political brands and concomitantly, political brand equity. Thus, maps of Conservative and Labour brands are produced, analysed and their brand equity discussed. The paper concludes by identifying further research opportunities pertaining to political brands suggested by this new methodological approach.

\section{The Rise of the Political Brand}


Brands are important. They are able to produce in consumers a perceived differentiation between competing offerings and they can play a critical role in directing consumer preference and choice (Aaker, 1991; Tybout and Sternthal, 2001: Kapferer, 2004). There has also been a steady stream of papers recognising political parties and or politicians as brands (Kavanagh, 1995; Kotler and Kotler, 1999; Harris and Lock, 2001; Smith, 2001; White and deChernatony, 2002; Schneider, 2004; Needham, 2005, 2006; Reeves et al., 2006; Scammell, 2007).

One reason for the increased research into the political brand is the changing nature of post-war Western Democracies. Kirchheimer (1966) suggests that viewing parties as brands is an inevitable response to the move from mass based to catch-all parties. Voters are less influenced by class affiliation and more likely to act like rational, economic actors when voting (Downs, 1957). So to win an election, "the catch-all party must have entered into millions of minds as a familiar object fulfilling in politics a role analogous to that of a major brand in marketing, of a universally needed and highly standardized article of mass consumption”(Kirchheimer, 1966, p. 192). However, a consequence of the 'catch-all' approach adopted by the main, national British political parties, as with many western democracies, is that they increasingly fight over the middle ground. Also, to secure this middle ground the parties end up offering 'valence' policies (Nelson, 1984) to the electorate wherein they all agree on the ends (such as the need to improve public services) and differ only on the means of achieving them. For voters, this increases the effort needed to differentiate between the parties.

Against these changes, many citizens have a low involvement with party politics. For them in particular, gathering political information is costly in terms of the effort needed to assimilate it versus the motivation to do so (Downs, 1957). As such it is reasonable to assume that low involvement voters will have relatively limited knowledge about political parties and their associative networks will be less complex than those of higher involvement voters. Nevertheless, low involvement voters are still able to use heuristics to make voting decisions (Sniderman et al., 1991; Popkin, 1994). Thus, for example, the leader's image, as a major and often dominant part of the overall brand ${ }^{1}$, has been identified as a heuristic for voter assessment of overall party competence, responsiveness and attractiveness (Clarke et al., 2004).

\section{A Consumer Versus a Managerial Approach to Political Branding}


Despite the structural and consumer-based reasons for more voters viewing political parties as they do other service brands, the application of branding in the political marketplace has been equivocal. Branding has been seen to produce unwanted effects such as narrowing the political agenda, increasing confrontation, demanding conformity of behaviour/message and even increasing political disengagement at the local level (Scammell, 1999; Lillekar and Negrine, 2003; Needham, 2005).

These criticisms derive from the application of branding principles in politics - what may be termed the managerial, normative approach as used on commercial brands (see, for example, Aaker and Joachimstaller, 2000). In mainstream academic research, branding is premised on a consumer-oriented perspective, investigating how consumers learn about brands (see Keller and Lehmann (2006) for an overview of this extensive, empirical, academic branding literature). The consumer-oriented paradigm of branding adopts a cognitive psychological approach which assumes that consumers build knowledge structures about an object (such as a political party) that is stored for retrieval in memory. It contends that, consumers have an innate motivation to learn about and decide about brands, both to know where to spend their money (or cast their vote) and to cope with the increasingly complex and over-communicated world that they live in. This approach offers numerous new theoretical perspectives from which to investigate the political brand ${ }^{2}$ and is the one adopted in this paper.

\section{Conceptualising the Political Brand as Consumer Memory}

Brands are not physical but intangible entities, being the associations about a particular object that are held in the memory of consumers (Keller, 1993). This idea is supported by learning theory and in particular the associative network memory model of consumer memory. Brand knowledge is made from individual pieces of information (called nodes). The theory assumes that such information is linked together in memory to form a more complex associative network (Collins and Loftus, 1975; Wyer and Srull, 1989); in this context a network of information about a given political party. This information is recalled from memory when a node is stimulated from rest by a process known as activation (de Groot, 1989). So, for example, the Conservative Party may be viewed as an information node to which other nodes may be associated such as its current leader, David Cameron (and associations linked to him - that he is relatively young, went sledging on a Norwegian glacier etc.); that it is the party of the countryside, low tax and 
so on. Seeing a party's leader on the television (or hearing their name/reading it in a paper) acts as a stimulus, producing spreading activation from memory to other political associations such as those mentioned above. Any association when stimulated has the potential to activate other brand nodes that are stored in memory.

From a consumer learning perspective therefore, the political brand is defined as an associative network of interconnected political information, held in memory and accessible when stimulated from the memory of a voter. Political marketing research to date has typically sought to measure a priori, views about political parties and their leaders, policies etc.. The number, type, strength and inter-relationship of the actual associations of the political brand held in the collective memories of an electorate (or sub-division thereof) have not been measured and as such the true nature of the political brand from an associative network perspective remains unknown. This is a major omission as it is from the associations held in memory that consumers form their attitudes and make decisions (Keller, 1993). By corollary, this is how voting decisions are also made.

\section{Measuring Political Brand Equity}

As we have seen, the brand is a source of competitive differentiation and given its importance, there has been much effort to measure the overall value of brands. Brand equity is the overall term for this value and is defined herein as the differential effect of brand associations on consumer response to the brand. "A brand is said to have positive (negative) customer-based brand equity when consumers react more (less) favourably to an element of the marketing mix for the brand than they do to the same marketing mix element when it is attributed to a fictitiously named or unnamed version of the product or service” (Keller, 1993, p. 1). Negative brand equity in politics was observed in the UK in 2005 when two sample groups were asked if they agreed with Conservative party policy on immigration. One group was told it was Conservative policy and its approval rating was 12 points lower than the group which was not told whose policy it was. After appointing a new leader (David Cameron) and dropping old/introducing more modern policies, the negative effect of the Conservative brand had all but disappeared by 2006 (Riddell, 2006) ${ }^{3}$. Respondents were using this new information on the party and its leader to appraise more positively the Conservatives. In so doing, the equity of the Conservative brand was enhanced. 
Numerous ways of measuring consumer-based brand equity have been forwarded (Na et al., 1999; Kish et al., 2001; Srinivasan et al., 2005). One notable and widely used approach conceptualises four dimensions of consumer based brand equity, namely, brand awareness, brand associations, perceived quality and brand loyalty (Aaker, 1991; Keller 1993) These dimensions have subsequently received empirical support (Yoo and Donthu, 2001; Pappu et al., 2005) and provide the structure for the discussion of political brand equity that follows.

Brand Awareness. Both Labour and Conservative Parties are clearly very strong in terms of awareness. Their unprompted recall (derived from the question "name the main political parties in the UK”) reveals, unsurprisingly, 100\% awareness for both brands from UK respondents. However, high recall, whilst being a necessary condition for equity, is not of itself sufficient. As we shall see later, brand recall stimulates related brand associations which may be positive (and add to equity), neutral or negative (and thus not add to a brand's equity).

Loyalty. In UK politics, using British Election Studies (BES) and British Election Panel Surveys (BEPS) over the period 1964-2001, Clarke et al. (2004) conclude that "very sizeable minorities change their party identifications” (p. 212). Currently about 70\% of voters stay with one party over consecutive elections and approaching a third shift their level of allegiance and or shift party altogether. There are two ways of viewing this. Psephologists such as Clarke et al. (2004) view this as evidence of "substantial, ongoing dynamics in partisanship in Britain” (p. 213). Marketers might think that keeping the loyalty of the clear majority of existing customers over a protracted period was a sign of high brand equity. ${ }^{4}$

Perceived Quality. To the best knowledge of the authors, the perceived quality of the political brand has not been researched directly at the time of writing. The extant service quality literature is however extensive and, using Zeithaml et al.’s (1990) seminal work, those dimensions that appear particularly apposite to politics are highlighted in the following table. Also provided are examples of recent political events where Labour's service quality may have been judged positively or negatively. 
Table 1. Potential Influences on the Perceived Quality of the Labour Party

\begin{tabular}{|c|c|c|}
\hline $\begin{array}{l}\text { Service Quality } \\
\text { Dimension }\end{array}$ & Features & $\begin{array}{l}\text { Political Events Allowing Service Quality } \\
\text { Judgement }\end{array}$ \\
\hline Credibility & $\begin{array}{l}\text { Trustworthiness, honesty and } \\
\text { believability }\end{array}$ & $\begin{array}{l}\text { Decision on Iraq war/weapons of } \\
\text { mass destruction (2002-3) } \\
\text { - Political sleaze (e.g. cash for honours) } \\
\text { (2006-7) }\end{array}$ \\
\hline Security & $\begin{array}{l}\text { Freedom from danger, risk or } \\
\text { doubt }\end{array}$ & $\begin{array}{ll}\text { - } & \text { Anti-terrorism actions (2001-2007) } \\
\text { - } & 7^{\text {th }} \text { July bombings in London (2005) }\end{array}$ \\
\hline Communication & $\begin{array}{l}\text { Listening and keeping } \\
\text { consumers involved }\end{array}$ & $\begin{array}{l}\text { - Blair’s ‘masochism’ election strategy } \\
\text { (2005) } \\
\text { - Labour’s ‘Big Conversation’ (2003) }\end{array}$ \\
\hline $\begin{array}{l}\text { Reliability/ } \\
\text { competence }\end{array}$ & $\begin{array}{l}\text { Ability to perform the } \\
\text { promised service }\end{array}$ & $\begin{array}{l}\text { Progress on targets in the NHS, } \\
\text { education etc (1998-2007) } \\
\text { - Inaccuracies over immigration figures } \\
\text { (2007) }\end{array}$ \\
\hline
\end{tabular}

Adapted from Zeithaml et al. (1990)

Over the 1983-2003 period, about three quarters of polled respondents agreed that both cabinet ministers and all politicians do not tell the truth (Worcester, 2003). There is also evidence of declining trust in political parties and politicians in the UK (Dermody and Hanmer-Lloyd, 2005). Added to these trends is the high overall level of perceived 'sleaze' with Labour, perceived as less sleazy than the Conservatives in 2001, now viewed as more sleazy (Ipsos-Mori, 2007). Taken as a whole, these measures of perceived quality suggest that both political parties are not strong.

Brand Associations. In measuring brand associations it is evident that they are not all of equal importance or positive and as such affect equity differently. Keller (1993) acknowledges this and uses brand association strength, favourability and uniqueness as measures of brand equity. Strength equates to how many associations the party brings to mind; Favourability, the positivity/negativity of these associations and Uniqueness, where associations are not shared with the opposition and thus a potential source of differentiation. Ideally, a powerful brand with high levels of brand equity will have 
strong and favourable associations overall and some of these will be unique on things important to the consumer/voter.

The rest of this paper is devoted to considering how to measure political brand associations and their contribution to overall brand equity. It is posited here that the associations of a political party are the basic source from which perceptions of brand quality are determined. In turn, the overall perception of the quality of the brand influences directly partisan loyalty and, subsequently, voting behaviour. As such, brand associations act as the basic cognitive building block of consumer-based brand equity. ${ }^{5}$

\section{Developing Mental Maps of Political Brands: a Methodology}

The main way of representing the memory of consumers is by using mental maps that reveal not only the associations held in memory but also how these are connected to each other (see Henderson et al., 1998 for an overview). However, the mapping approach has been very time consuming and requiring intensive training for the researcher. A recent addition from John et al. (2006) has forwarded a more straightforward but empirically reliable and valid method, Brand Concept Maps (BCM), for collecting, aggregating and producing a single consensus map that represents the associative network for a particular group of a particular brand.

Rather than repeat the John et al. (2006) BCM methodology, we focus on showing how we a) applied BCM to the political market, b) used BCM to analyse the characteristics of the political market and c) further developed the method to consider the power of the political brand (i.e. its brand equity). In doing this, the paper contributes to the existing associative network methodology and produces improved ways of measuring brand maps per se.

The BCM approach uses a stimulus to trigger memory about a brand. The stimulus used in this research was the party name (Conservative or Labour). The choice of using the party as the stimulus (as opposed to the leader) is predicated on the fact that the party, like corporate brands generally, offers the umbrella of cohesion, recognition and predictability (Singer, 2002). They have also been identified as providing signals (information) that are simple, credible, salient and continuous over long periods of time (Tomz and Sniderman, 2004). The greater longevity and umbrella function suggests the party name as stimulus will cover relevant leader, policy and other important political brand associations as held in memory by the public. 
The research was based on a sample of two discrete groups of undergraduate students at an English University, one for the elicitation stage $(\mathrm{N}=132)$ and one for the actual mapping stage $(\mathrm{N}=62)$. Whilst clearly not representative of the electorate at large, their relative homogeneity as a group (by age, sex, education etc.) was useful for piloting the method in the area (Calder et al., 1981).

The first step in BCM research is the Elicitation phase wherein the first cohort were asked to write down the associations (unprompted) that came to mind when they thought of a given party. Respondents chose the party they felt greatest affinity with. Uncommitted respondents were randomly allocated a party. This resulted in 60 Labour and 72 Conservative responses. These produced an unprompted listing of approximately 50 separately identifiable associations for both Labour and Conservative. This list was then reduced to 23 (Labour) and 26 (Conservative) by removing associations mentioned by less than 4 respondents. A listing of the associations that made it on to the consensus maps is shown in Table 2 that follows. The associations that failed to appear on the consensus maps can be found in Table 4 in the Appendix.

The second, Mapping phase entailed using a different subset of the student population. They were shown an existing brand map example (of the VW Beetle) as a means of instruction on how to construct a brand map. ${ }^{6}$ The research group were then asked to identify the political party they felt closest to. They were next shown the associations for their chosen party as derived from the Elicitation stage and asked to construct their own map for their preferred party. Respondents were also told that they were entirely at liberty to add their own associations; one such free association (First female Prime Minister) made it onto the final Conservative consensus map. Participants were asked not only to identify those associations they thought relevant but also to link associations together. When this was complete, respondents were asked to indicate the strength of the link between associations using single, double or triple lines. Further, respondents were asked to consider the associations on their maps and to indicate whether they considered the association to be positive, negative or neutral.

At the third, Aggregation stage, the individual brand maps were used to generate a single brand consensus map for each party. In summary, this was done by a) identifying the (first and second-order) brand associations that feature on the majority of individual maps; b) adding (first-order) associations to the map that were linked to the party more often than not; c) adding the remaining (second-order) associations by linking them to the already positioned first-order associations; d) adding (third-order) associations to the 
map- these are included due to high frequency links to first and or second-order associations; e) calculating the average "weight" for each link, based on the weights in the individual maps and f) attributing positive or negative signs to each mapped association.

\section{Analysing the Brand Associations of Labour and Conservative Brands}

The maps produced during the Aggregation stage are provided in Figures 1 and 2 for Conservative and Labour respectively. They reflect the associations about a party by respondents who expressed a preference (either strong or slight) for that party. There were no Conservative supporters mapping Labour and vice versa. Given their positive affiliation with the party brand, the resultant maps are relatively positive also.

The Party and its first-order associations are shown shaded; second-order associations are un-shaded with a solid outline; third-order associations are shown with dashed outlines.

By way of a caveat, when considering the consensus maps below it should be noted that the maps reflect the views held by the sample at a given point in time (October, 2007). Given the major decline in Labour's popularity since that time and the concomitant improvement in the Conservative's, we would expect this to be reflected in the maps themselves. For example, the credit crunch and spiralling fuel and food prices of 2008 are likely to figure as negative associations in a current map of the Labour brand. Also, as these 'events' have sparked speculation about the future of Gordon Brown as Prime Minister, we might well see changes in his association as a 'Strong Leader' in a current (August 2008) Labour map (see the footnote for more discussion of this). ${ }^{7}$

Figure 1: A Brand Consensus Map of the Conservative Party by Conservative Supporters 


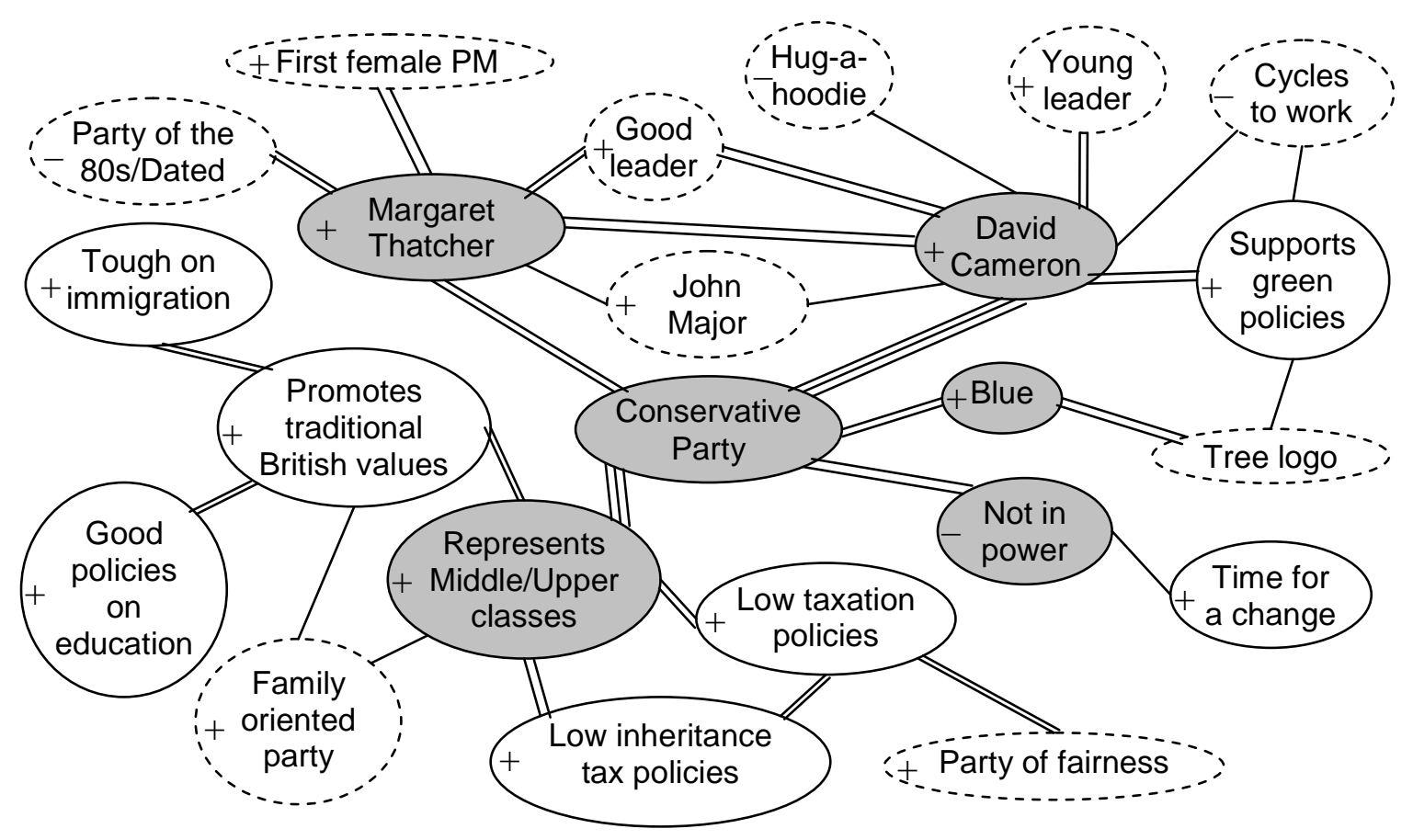

Figure 2: A Brand Consensus Map of the Labour Party by Labour Supporters

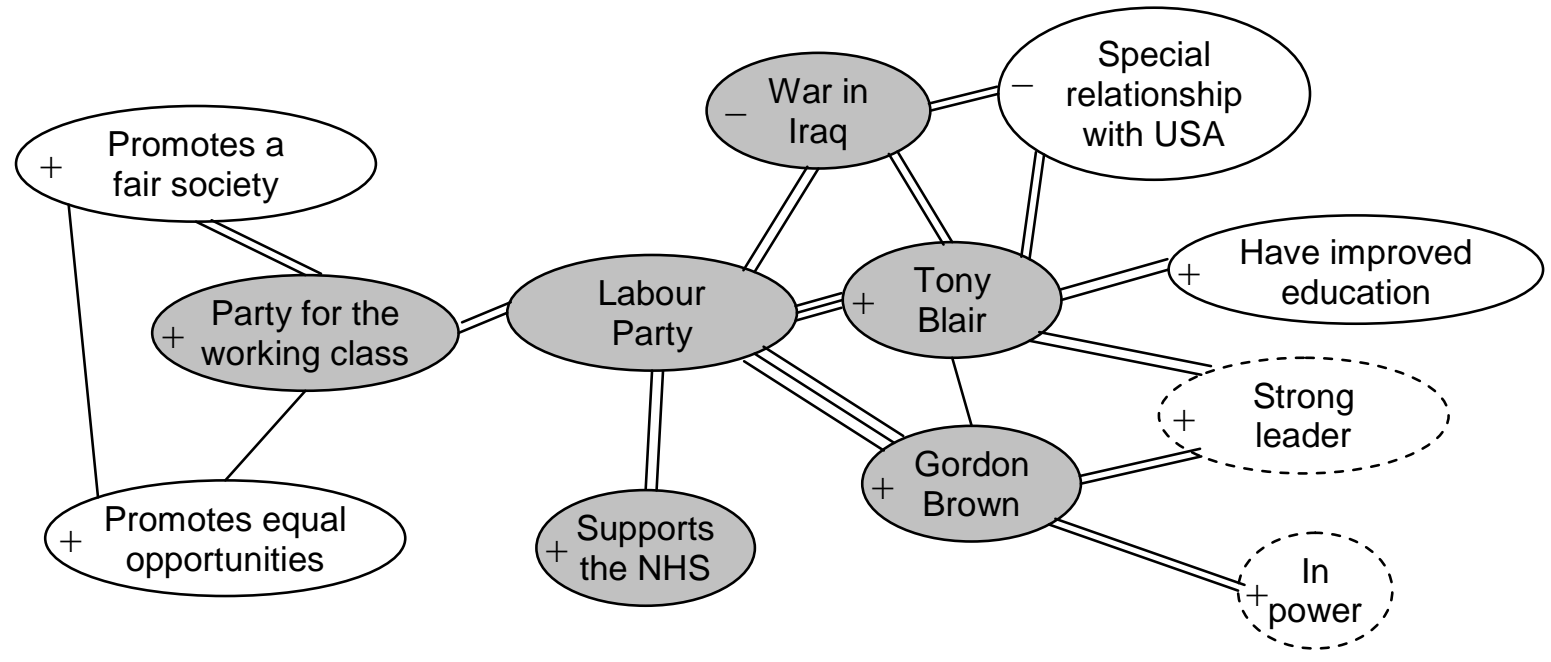


General Characteristics: Firstly, it is useful to gain a broad prima facie impression from the maps and this is done by simply 'eyeballing' them, looking for interesting features. This process reveals that the Conservative map clearly contains more associations than the Labour map - the implications of this will be discussed in greater detail later. Both maps have a similar structure insofar as personality associations and policy based associations appear as separate discrete groupings. Both maps also contain a very similar structure linking party, leader, past leader and good/strong leadership.

Surprisingly, the maps show that David Cameron is linked with more associations than Gordon Brown, the Prime Minister; when respondents think of David Cameron, many more associations are triggered in memory. This would perhaps be a concern for Labour party strategists.

However, much information from the maps is not apparent from a visual inspection and a quantitative analysis is required to highlight this hidden information. Our primary concern was to identify those associations that consumers perceive to be the most important for the political brand. In network analysis this is denoted by the brand association's centrality within the consensus map.

Central Characteristics: Centrality measures where each association is in a map. Those features scoring more highly can be regarded as being more important, fundamental or central to the brand. Three commonly used centrality measures were used: degree centrality (Freeman, 1979; Czepiel, 1974) - how many associations are directly linked to each association; betweenness centrality (Freeman, 1979) - what proportion of geodesic (shortest) paths in the map link through a particular association and closeness centrality (Sabidussi, 1966) - how close an association is to the other associations in the map. By using these three measures together, it is possible to identify the central associations of the map, and hence the party. Details of the formulae involved in calculating these measures can be found in Appendix 1. The centrality values for the maps in Figures 1 and 2 are shown in Table 2 below.

The centrality measures reveal that for the Conservatives, there is very broad agreement between the three measures as to what are the key branded features: Conservative Party; David Cameron; Represents Middle/Upper Classes and, Margaret Thatcher. For Labour, there is similar agreement: Labour Party; Gordon Brown; Party for the Working Class and Tony Blair. Further analysis of the tables reveals that for the Conservatives, David Cameron is ranked higher than Margaret Thatcher with respect to all three measures of 
centrality. More surprisingly, for Labour, the former leader, Tony Blair, is more central to the brand than the current leader, Gordon Brown.

Table 2: Centrality Values for the Consensus Maps (Figures 1 and 2)

\begin{tabular}{|l|l|l|l|}
\hline Conservative & \multicolumn{3}{|l|}{ Centrality } \\
\hline Association & Deg. & Bet. & Clo. \\
\hline Conservative Party & 5 & 150.50 & 0.024 \\
\hline David Cameron & 8 & 90.50 & 0.021 \\
\hline Margaret Thatcher & 6 & 53.50 & 0.020 \\
\hline Middle/Upper Classes & 5 & 117.00 & 0.020 \\
\hline Trad'l British Values & 4 & 41.00 & 0.015 \\
\hline Green Policies & 3 & 8.00 & 0.016 \\
\hline Tough on Immigration & 1 & 0.00 & 0.012 \\
\hline Blue & 2 & 12.50 & 0.017 \\
\hline Low Inheritance Tax & 2 & 0.00 & 0.015 \\
\hline Low Taxation Policies & 3 & 21.00 & 0.015 \\
\hline Time for a Change & 1 & 0.00 & 0.012 \\
\hline Good Policies Educ’n & 1 & 0.00 & 0.012 \\
\hline Not in Power & 2 & 21.00 & 0.016 \\
\hline Young Leader & 1 & 0.00 & 0.015 \\
\hline John Major & 2 & 0.00 & 0.015 \\
\hline Family Oriented Party & 2 & 0.00 & 0.015 \\
\hline Cycles to Work & 2 & 0.00 & 0.015 \\
\hline Good Leader & 2 & 0.00 & 0.015 \\
\hline Party of 80’s/Dated & 1 & 0.00 & 0.014 \\
\hline Party of Fairness & 1 & 0.00 & 0.011 \\
\hline Tree Logo & 2 & 1.50 & 0.014 \\
\hline Hug-A-Hoodie & 0.00 & 0.015 \\
\hline First Female PM & 0.00 & 0.014 \\
\hline
\end{tabular}

\begin{tabular}{|l|l|l|l|}
\hline Labour & \multicolumn{3}{l|}{ Centrality } \\
\hline Association & Deg. & Bet. & Clo. \\
\hline Labour Party & 5 & 32.00 & 0.059 \\
\hline War In Iraq & 3 & 2.50 & 0.045 \\
\hline Tony Blair & 6 & 20.00 & 0.056 \\
\hline Gordon Brown & 4 & 16.50 & 0.050 \\
\hline Spec. Rel. - USA & 2 & 0.00 & 0.037 \\
\hline Improved Educ'n & 1 & 0.00 & 0.036 \\
\hline For Working Class & 3 & 18.00 & 0.043 \\
\hline Supports The NHS & 1 & 0.00 & 0.037 \\
\hline Promotes Fair Society & 2 & 0.00 & 0.031 \\
\hline Promotes Equal Opps & 2 & 0.00 & 0.031 \\
\hline In Power & 1 & 0.00 & 0.033 \\
\hline Strong Leader & 2 & 0.00 & 0.038 \\
\hline
\end{tabular}

\section{Measuring the Equity of Political Brands}

As previously identified, Keller (1993) postulates that the strength, favourability and uniqueness of a brand's associations are a measure of brand equity. What remains is to operationalise these measures within the consensus maps of the Labour and Conservative parties created and discussed above. To this end, the work of Krishnan 
(1996) on measuring brand equity via brand associations is used and applied to the brand maps of Labour and the Conservatives.

Strength. The number of associations that come to mind when asked to consider a party is one measure of equity. A party with many associations has more routes between associations and thus a greater number of ways by which associations can be recalled from memory via spreading activation. So, based upon the consensus maps in Figures 1 and 2, the Conservative party with 22 associations would be considered far stronger than the Labour party with 11 associations. However, further analysis based on the categorisation (by BCM) of associations as either first-order (frequently mentioned/linked and directly linked to the party), second-order (frequently mentioned/linked, but not directly linked to the party) and third-order (included due to the frequency of linkage to a first or second-order association) presents a slightly more balanced view (see Table 3). Thus, it can be seen that both parties have the same number of associations directly linked to the party. The Conservatives however, show greater strength in terms of the number of associations that are triggered when the firstorder associations come to mind. The significance of this can only be gauged by considering the nature of these further associations; having more associations will only be of value if the associations are favourable.

Table 3: Number of Associations by Type

\begin{tabular}{|l|l|l|}
\hline Type of Association & Labour & Conservative \\
\hline First-Order & 5 & 5 \\
\hline Second-Order & 4 & 7 \\
\hline Third-Order & 2 & 10 \\
\hline Total & 11 & 22 \\
\hline
\end{tabular}

Favourability. As the number of associations is not necessarily a sign of equity (for example, McDonalds may have a lot of negative associations for some consumers), it is necessary to measure the net valence of the associations (Krishnan, 1996), that is (\# of positive associations - \# of negative associations) / (total number of associations). For Labour, this calculation produces a favourability score of 0.63 . For the Conservatives, favourability is $0.68^{8}$ with 1 being complete favourability. Thus, the Conservative brand is viewed marginally more favourably than Labour. Further analysis of these 
figures reveal that in both cases, in excess of $75 \%$ of associations were positively judged and overall, the respondents had a high level of favourability for their preferred party as might be expected.

Uniqueness. Krishnan (1996) measures uniqueness as the proportion of associations that are unique to the brand as compared to the competition. As the two elicited lists contained many different associations, the resulting consensus maps were expected to have little in common and show two unique brands. The maps in fact share three associations, i.e. Party of fairness/Promotes a fair society; Good policies on education/Have improved education and Good leader/Strong leader. The remaining associations (19 for Conservative, 8 for Labour) are unique. Measuring the proportion of unique associations reveals that Conservatives have 19/22 $=86 \%$ unique associations compared to $8 / 11=73 \%$ for Labour. The analysis confirms that the party brands are in fact quite unique for the sampled groups

\section{Discussion of Results}

Analysis of the general and central brand characteristics has confirmed the importance of the leader with the party brand. For Labour it also reveals how Blair is still a major part of the brand. Though Blair still has strong negative associations (Iraq and the USA), his link to Brown is less strong, whilst Brown himself is not linked directly with either negative association. The implications are that, whereas Al Gore was criticised for not using Clinton in the 2000 Presidential race, Brown and Labour would be well advised to distance themselves from Blair (assuming the associations remain the same at the next election).

As for the Conservatives, it is surprising, and potentially worrying from a party seeking to re-position itself firmly as a modern, centre-right democratic party that Thatcher still occupies such a central position - especially as she has been out of office for 17 years (i.e. since the infancy of the respondents) and there have been five leaders since her, the majority of whom do not register in the collective memory.

The greater number of associations in the Conservative map was also unexpected, as the party of opposition is at a disadvantage in communicating with the electorate. It suggests that Cameron has been quite successful in positioning himself in the minds of this sample on some (environmental) issues and symbolically (his youthfulness). It also 
reveals that the party has managed to create strong associations with issues such as inheritance taxation, education, traditional British values and its core representation of the upper/middle classes. Labour on the other hand, although it does have associations with 'traditional' issues (supporting the NHS and education; representing the working classes), is notably lacking associations on more contemporary issues such as immigration, environmentalism, controlling terrorism etc.. The most notable revelation is however the lack of associations with Brown himself beyond his leadership strength. So despite all his time as Chancellor and now as PM, Labour supporters do not associate him with much and certainly not with any 'vision thing'.

When considering the brand equity of the two main political parties it is not sufficient to consider the three characteristics of powerful brand associations in isolation (Keller, 1998). In terms of Strength, it is clear that both parties have a similar number of firstorder associations. The Conservatives score more strongly when it comes to secondorder and third-order associations. Both parties’ maps are broadly favourable, but it is clear that Tony Blair, a key central association for Labour, is linked strongly to two very negative associations, i.e. the war in Iraq and the special relationship with the USA. Both Labour and Conservative brands exhibited high levels of unique associations, with Conservative having a higher number and proportion of unique associations. This is at clear odds with the idea that political parties are becoming increasingly similar, as a result of valence politics. The respondents identified quite different associations and resultant maps.

Taken together, the Conservative brand has more strength than Labour, is as favourably perceived and has more unique associations and as such has the greater equity. This conclusion of course applies only to the groups sampled. It also must be set against the background of the political marketplace; of high political brand awareness but significant brand switching amongst voters and a low perceived quality of the service political parties provide overall.

\section{Further Research}

The maps presented herein provide a wealth of insight both into the brand associations of a sample group and the linkages between them. As such the method provides a significant step forward in measuring the political brand. However, it is noticeable that, although there are emotional/affective elements of the maps ${ }^{9}$, the associations elicited 
from the sample are largely cognitive associations with the party brand. We have already identified that an increasing number of voters have a low involvement with politics. In addition, it has been argued that more emotional learning than cognitive informational learning takes place under conditions of low involvement (Heath and Nairn, 2005; Heath et al, 2006) and this is in line with research identifying the importance of emotion in guiding voting decisions (Burkitt 2002, Richards 2004, Westen 2007).

As such, future research using the BCM approach should consider developing the elicitation stage to allow more emotional associations with the brand to be identified. This would require using traditional qualitative methods such as focus groups and depth interviews. John et al (2006) offer up the Zaltman Metaphor Elicitation Technique (Zaltman and Coulter, 1995) as another possible qualitative methodology to develop the range and type of associations that are mapped.

In this paper we have concentrated on illustrating brand mapping and brand equity measurement as applied to the two main UK political parties. Clearly, BCM may also be used to compare and contrast other important electoral groups. So for example, future research could target floating/non aligned voters in marginal seats to see what associations of the competing political brands are in their collective memories, accessible for use when voting - and thus likely to influence the outcome of a general election.

Another interesting possibility with this method would be to adopt a longitudinal approach over the duration of an election campaign to see a) how, if at all, the campaign influences the mental maps of voters and b) if there are changes, whether these are affecting changes in voting intention (to vote or abstain; to switch allegiance). Longitudinal research could also compare and contrast election campaign affects across differing 'segments' ${ }^{10}$ using the BCM approach.

A more protracted longitudinal study that covered the period of a parliament or longer would allow for the analysis of how significant events (war, sleaze, economic mismanagement etc.) affect consumer memory of political brands and potentially shed light on tipping points in voting intentions.

Finally, the BCM approach can also be used with differing foci. So for example it could be used with the leader as the main stimulus in the map's creation. Parties might also be 
interested to analyse the memory maps of voters on specific policies (for example the Conservatives on how they are perceived on the EU, Public Services etc.).

\section{Conclusions}

The paper has analysed the two main political parties in the UK as brands. To do this it has conceptualized the political brand as consumer learning and provided a new method for measuring the brand equity of political parties using consumers' brand associations. The findings are limited in their wider application by their focus on a convenience sample of students. The method however does confirm the relative ease of developing maps and, as the further research section suggests, the potential to develop this method in politics is great, both in the UK and other democratic societies where the views of the public are important. Its wider application will produce a greater understanding of how voters understand and react to political parties. The approach outlined in this paper promises to provide a strong impetus for further empirical, theoretically supported research into this important area of political marketing.

\section{References}

Aaker,D. (1991), Managing Brand Equity, The Free Press, New York.

Aaker, D. and Joachimsthaler, E. (2000), Brand Leadership, The Free Press, New York. Burkitt, C. (2002), “Are You Less Emotionally Intelligent Than Blair?”, paper presented to the annual conference of the Political Studies Association, Aberdeen, UK.

Butler, P. and Collins, N. (1999), “A Conceptual Framework for Political Marketing”, in Newman, B.I., (ed.), Handbook of Political Marketing, Sage, Thousand Oaks, California.

Calder, B.J., Phillips L.W. and Tybout, A.M. (1981), "Designing Research for Application,” Journal of Consumer Research, Vol. 8, September, pp. 197-207.

Clarke, H.D., Sanders, D., Stewart, M.C. and Whiteley, P. (2004), Political Choice in Britain, Oxford University Press, Oxford.

Collins, A.M. and Loftus, E.F. (1975), “A spreading activation theory of semantic processing”, Psychological Review, Vol. 82, No.6, pp. 407-28. 
Czepiel, J.A. (1974), “Word-of-Mouth Processes in the Diffusion of a Major Technological Innovation”, Journal of Marketing Research, Vol. 11, May, pp.172-180. de Groot, A.M.B. (1989), “Representational aspects of word imageability and word frequency as assessed through word association”, Journal of Educational Psychology: Learning Memory and Cognition, Vol. 15, No. 5, pp 824-845.

Dermody, J. and Hanmer Lloyd, S. (2005), “Safeguarding the Future of Democracy: (Re)Building Young People’s Trust in Parliamentary Democracy”, Journal of Political Marketing, Vol. 4, No. 2/3, pp. 115-133.

Downs, A. (1957), An Economic Theory of Democracy, Harper, New York.

Forehand, M., Gastil, J. and Smith, M.A. (2004), “Endorsement as Voting Cues:

Heuristic and Systematic Processing in Initiative Elections”, Journal of Applied Social Psychology, Vol. 34, No. 11, pp. 2215-2233.

Freeman, L.C. (1979), “Centrality in Social Networks Conceptual Clarification”, Social Networks, Vol. 1, No. 3, pp. 215-239.

Harris, P. and Lock, A. (2001), "Establishing the Charles Kennedy Brand: A Strategy for an Election the Result of which is a Foregone Conclusion”, Journal of Marketing Management, Vol. 17, No. 9-10, pp. 943-956.

Heath, R. and Nairn, A. (2005), "Measuring Affective Advertising: Implications of Low Attention Processing and Recall”, Journal of Advertising Research, Vol. 45, No. 2, pp. 269-281.

Heath, R., Brandt, D. and Nairn, A. (2006), “Brand relationships: Strengthened by Emotion, Weakened by Attention”, Journal of Advertising Research, Vol. 46, No. 4, pp. 410-419.

Henderson G.R., Iacobucci D. and Calder B.J. (1998), “Brand Diagnostics: Mapping Branding Effects Using Consumer Associative Networks”, European Journal of Operational Research, Volume 111, Number 2, pp. 306-327.

Henneberg, S. (2006), “The views of an advocatus dei: political marketing and its critics”, Journal of Public Affairs, Vol. 4, No. 3 , pp. 225 - 243. Ipsos-Mori (2007), “Attitudes Towards Sleaze”, http://www.ipsos-mori.com/polls/ trends/sleaze.shtml.

John, D.R., Loken, B., Kim, K. and Basu Monga, A. (2006), “Brand Concept Maps : A Methodology for Identifying Brand Association Networks”, Journal of Marketing Research, Vol. 43, No. 4, pp. 549-563. 
Kapferer, J-N. (2004), The New Strategic Brand Management. Creating and Sustaining Brand Equity Long Term, Kogan Page, London.

Kavanagh, D. (1995). Election Campaigning: The New Marketing of Politics, Blackwell, Oxford, UK.

Keller, K.L. (1993), “Conceptualizing, measuring, and managing customer-based brand equity”, Journal of Marketing, Vol. 57 No.1, pp.1-22.

Keller, K.L. (1998), Building, Measuring and Managing Brand Equity, Prentice Hall, New Jersey.

Keller, K.L. (2002), “Branding and Brand Equity”, in Weitz, B.A. and Wensley, R., (ed.), Handbook of Marketing, Sage, Thousand Oaks, California.

Keller, K.L. and Lehmann, D. (2006), “Brands and branding: Research Findings and Future Priorities”, Marketing Science, Vol. 25, No. 6. pp. 740-759.

Kirchheimer, O. (1966), “The Transformation of the Western European Party Systems", in Lapalombara, H. and Weiner, M., (eds.), Political Parties and Political Development, Princeton University Press, Princeton, N.J., pp. 177-200.

Kish, P, Riskey, D. R. and Kerin, R. A. (2001), "Measurement and tracking of brand equity in the global marketplace: the PepsiCo experience”, International Marketing Review, Vol. 18, No. 1, pp. 91-96.

Kotler, P. and Kotler, N. (1999), “Generating effective candidates, campaigns, and causes”, in Newman, B., (ed.), Handbook of Political Marketing, Sage, Thousand Oaks, pp.3-19.

Krishnan, S.H. (1996), “Characteristics of Memory Associations: A Consumer-Based Brand Equity Perspective”, International Journal of Research in Marketing, Vol. 13, 389-405.

Lilleker, D. and Negrine, R. (2003). “Not big brand names but corner shop: Marketing politics to a disengaged electorate”, Journal of Political Marketing, Vol. 2, No.1, pp. 5575.

Lock A. and Harris P. (1996), “Political Marketing - Vive la Différence!”, European Journal of Marketing, Vol. 30, No. 10/11, pp. 14-24.

Na, W. B., Marshall, R. and Keller, K. L. (1999), “Measuring brand power: validating a model for optimizing brand equity”, Journal of Product and Brand Management, Vol. 18, No. 2/3, pp. 170-184.

Needham, C. (2005), "Brand Leaders: Clinton, Blair and the Limitations of the Permanent Campaign”, Political Studies, Vol. 53, p. 343-361. 
Needham, C. (2006), “Brands and Political Loyalty”, Brand Management, Vol. 13, No. 3, pp. 178-187.

Nelson, B.J. (1984), Making an Issue of Child Abuse: Political Agenda Setting for Social Problems, University of Chicago Press, Chicago.

O’Shaugnessy, N. (2001), “The Marketing of Political Marketing”, European Journal of Marketing, Vol. 35, No. 9/10, pp. 1047-1057.

Pappu, R., Quester, P. G. and Cooksey, R. W. (2005), “Consumer-based brand equity: improving the measurement - empirical evidence”, Journal of Product and Brand Management, Vol. 14, No.3, pp. 143-154.

Popkin, S. L. (1994), The Reasoning Voter, The University of Chicago Press, Chicago. Reeves, P., de Chernatony, L. and Carrigan, M. (2006), "Building a Political Brand: Ideology Or Voter- Driven Strategy”, Journal of Brand Management, Vol. 13, No. 6, pp. 418-428.

Richards, B. (2004), “The Emotional Deficit in Political Communications”, Political Communication, Vol. 21, No. 3, pp. 339-352

Richins, M. L. (1997), “Measuring Emotions in the Consumption Experience”, Journal of Consumer Research, Vol. 24, September, pp. 127-145.

Riddell, P. (2006), “The Tory brand is paying off. All it needs now is some good products”, The Times Online, January $11^{\text {th }}$, http://www.timesonline.co.uk/tol/news/ politics/article787103.ece Sabidussi, G. (1966), “The Centrality Index of a Graph”, Psychometrika, Vol. 31, No. 4, pp. 581-603.

Scammell, M. (1999), "Political marketing: Lessons for political science”, Political Studies, Vol. 47, No. 4, pp. 718-739.

Scammell, M. (2007), "Political Brands and Consumer Citizens: The Rebranding of Tony Blair”, The ANNALS of the American Academy of Political and Social Science, Vol. 611, No. 1, pp. 176-192.

Schneider, H. (2004), "Branding in Politics - Manifestations, Relevance and IdentityOriented Management”, Journal of Political Marketing, Vol. 3, No. 3, pp. 41-67. Singer, C. (2002), “Bringing Brand Savvy to Politics,” Brandweek, Vol. 43, No. 34, p. 19.

Smith, I.G. (2001), "The 2001 General Election: Factors Influencing the Brand Image of Political Parties and their Leaders", Journal of Marketing Management, Vol. 17, No. 9/10, pp. 1058-1073. 
Sniderman, P.M., Brody, R.A. and Tetlock, P.E. (1991), Reasoning and Choice. Explorations in Political Psychology, Cambridge University Press, Cambridge.

Srinivasan, V. S., Park, C.S. and Chang, D.R. (2005), "An Approach to the

Measurement, Analysis, and Prediction of Brand Equity and Its Sources," Management Science, Vol. 51, No. 9, pp. 1433-1448.

Tomz, M. and Sniderman, P. (2004), “Constraint in Mass Belief Systems: Political Brand Names as Signals”, paper presented at the annual meeting of the American Political Science Association, Chicago.

Tybout, A.M. and Sternthal, B. (2001), “Brand Positioning”, in Iacobucci, D., (ed.), Kellogg on Marketing, John Wiley, New York, pp. 31-57.

Westen, D. (2007), The Political Brain: The Role of emotion in Deciding the fate of the Nation, Public Affairs, New York.

White, J. and de Chernatony, L. (2002), “New Labour: A Study of the Creation, Development and Demise of a Political Brand”, Journal of Political Marketing, Vol. 1, No. 2/3, pp. 45-52.

Worcester, R.M. (2003), “Whom Do We Trust? Neither Politicians Nor Journalists!”, http://www.ipsos-mori.com/publications/rmw/whomdowetrust.shtml.

Wyer, R.S. and Srull, T.K. (1989), “Person memory and judgement”, Psychological Review, Vol. 96, No. 1, pp. 58-83.

Yoo, B. and Donthu, N. (2001), “Developing and Validating a Multidimensional Consumer-Based Brand Equity Scale”, Journal of Business Research, Vol. 52, No. 1. pp. 1-14.

Zaltman, G. and Coulter, H. (1995), "Seeing the Voice of the Customer: MetaphorBased Advertising Research”, Journal of Advertising Research, Vol. 35, July August, pp. 35-51.

Zeithaml, V., Parasuraman, A. and Berry, L. (1990), Delivering Quality Service: Balancing Customer Perceptions and Expectations, The Free Press, New York.

\section{Appendix}


Degree Centrality for association $k=\sum_{i=1}^{n} a_{i k}$ where $n$ is the number of associations in the consensus map, $a_{i k}=1$ if associations $i$ and $k$ are directly connected in the consensus map and 0 otherwise.

Betweenness Centrality for association $k=\sum_{i=1, i \neq k}^{n-1} \sum_{j=i+1, j \neq k}^{n} b_{i j k}$ where $b_{i j k}=\frac{g_{i j}(k)}{g_{i j}} \cdot g_{i j}$ is the number of shortest paths connecting associations $i$ and $j$ in the consensus map and $g_{i j}(k)$ is the number of the shortest paths that pass through association $k$.

Closeness Centrality for association $k=\left[\sum_{i=1}^{n} d_{i k}\right]^{-1}$ where $d_{i k}$ is the number of links in the shortest path linking associations $i$ and $k$.

Table 4: Associations produced during the elicitation phase not appearing in the consensus maps.

\begin{tabular}{|l|}
\hline Conservative \\
\hline Better than the Labour Party \\
\hline Euro-sceptics \\
\hline Good policies for the NHS \\
\hline New/Innovative/Progressive Party \\
\hline Strong Party \\
\hline
\end{tabular}

\begin{tabular}{|l|}
\hline Labour \\
\hline Better than the Conservative Party \\
\hline Election wins \\
\hline Increased Taxes Through Stealth \\
\hline New Labour/Third Way \\
\hline Party of fair taxation \\
\hline Pro miners/unions \\
\hline Produced economic prosperity \\
\hline Pro-Europe \\
\hline Red \\
\hline Rose logo \\
\hline Supports civil liberties \\
\hline Supports the welfare state \\
\hline
\end{tabular}

\footnotetext{
${ }^{1}$ The relative importance of the leader versus the party has not been fully researched in branding terms. The leader will often have the strongest and clearest associative meaning as his/her image/personality is more easily identifiable (Schneider, 2004), though this may be positively (e.g. Blair pre the Iraq war) or negatively perceived (e.g. Thatcher pre the Falklands war). The party, conversely, has strength in that it is more constant than a leader/politician (Singer, 2002). In practice, at any one point in time the leader or the party may be the strongest in associative memory terms.
} 


\footnotetext{
${ }^{2}$ For example, brand knowledge theory underpins source credibility, cognitive consistency, schema congruity and affect transfer -and these all offer potential novel insight into political marketing.

${ }^{3}$ Negative brand equity is also displayed for the British National Party, a race based party in the U.K.. The negativity applies across a wide range of their policies in addition to those relating to immigration.

${ }^{4}$ In commercial markets, high brand loyalty is closely linked to purchase and financial success. In politics, loyalty often matters less than a much smaller number of floating voters switching between parties.

${ }^{5}$ This is particularly true with valence based voting behaviour wherein trust and competence to best implement policies that are similar across parties is forwarded as a major dynamic of voting behaviour (see Clarke et al. (2004)).

${ }^{6}$ This brand map was the same as used by John et al. (2006), amended to make more relevant to the sample.

${ }^{7}$ Towards the end of 2007 when the research was conducted, Labour, and Gordon Brown in particular, were still in a honeymoon period after the exit of Tony Blair. This period has definitely now ended as a number of negative 'events' (such as the credit crunch and rocketing food and oil prices) have damaged the Prime Minister and the Labour party. These events and Labour's apparent inability to deal with them will have resulted in new, negative learning about the brand. Unsurprisingly then, in the four month period since April 2008, the Conservatives have held a double digit percentage lead over Labour. During the same period Labour has lost several by-elections, most notably its 25th safest seat in Glasgow East to the Scottish National Party with a 24\% swing against them. Clearly, an election in August 2008 would lead to a Labour rout. As such, it is inevitable that the maps developed herein for both parties will no longer reflect the current perceptions of both parties. Indeed, as an antecedent factor for voting behaviour, we would argue that it is the evolution of voter associations with the party brands that is a core factor causing the changes in voting intention. Whatever the current state of these maps, the structural feature of the UK's first past the post electoral system puts greater importance on the nature of mental maps prior to the next election in 2009 or 2010 and in particular those of floating voters in marginal seats.

${ }^{8}$ Note that "Not in Power" has been treated as a positive; this is actually a favourable association.

${ }^{9}$ For example, it is reasonable to assume that the positive judgement of the Conservatives' 'Promotes traditional British values' association is indicative of emotions such as happy and pleased with the brand on this. Conversely, the negative judgement of Labour's 'War in Iraq' association is indicative of emotions such as anger and possibly shame (See Richins (1997) for a fuller listing of consumer emotions). ${ }^{10}$ For example, British Social Attitudes' floating voters/non aligned, residual identifiers, sympathisers and partisans.
} 